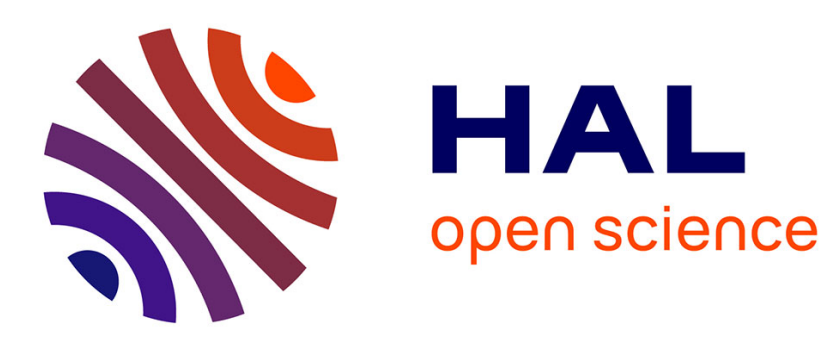

\title{
Carbonate dissolution by reef microbial borers: a biogeological process producing alkalinity under different pCO2 conditions
}

\author{
Aline Tribollet, Anne Chauvin, Pascale Cuet
}

\section{To cite this version:}

Aline Tribollet, Anne Chauvin, Pascale Cuet. Carbonate dissolution by reef microbial borers: a biogeological process producing alkalinity under different pCO2 conditions. Facies, 2019, 65 (2), 10.1007/s10347-018-0548-x . hal-02193013

\section{HAL Id: hal-02193013 \\ https://hal.science/hal-02193013}

Submitted on 24 Sep 2019

HAL is a multi-disciplinary open access archive for the deposit and dissemination of scientific research documents, whether they are published or not. The documents may come from teaching and research institutions in France or abroad, or from public or private research centers.
L'archive ouverte pluridisciplinaire HAL, est destinée au dépôt et à la diffusion de documents scientifiques de niveau recherche, publiés ou non, émanant des établissements d'enseignement et de recherche français ou étrangers, des laboratoires publics ou privés. 
Carbonate dissolution by reef microbial borers:

\section{A biogeological process producing alkalinity under different $\mathrm{pCO}_{2}$ conditions}

(3)

(1)

Tribollet $\mathrm{A}^{\mathrm{a}}$, Chauvin $\mathrm{A}^{\mathrm{b}}$, Cuet $\mathrm{P}^{\mathrm{b}}$

${ }^{a}$ Centre IRD de Nouméa, UMR LOPB, 101 Promenade Laroque, 98848 Nouméa Cedex, Nouvelle-Calédonie. ORCID : \#0000-0003-2385-3682. aline.tribollet@ird.fr

bUMR ENTROPIE (UMR450 IRD, UMR9220 CNRS, Université de La Réunion) and Laboratoire d'Excellence CORAIL, Université de La Réunion, 15 Avenue René Cassin, CS 92003, 97744 Saint-Denis Cedex 9, La Réunion, FR.pascale.cuet@univ-reunion.fr

Corresponding author: Aline Tribollet, Current address: IRD-Sorbonne Universités (Univ. Paris 6) UPMC-

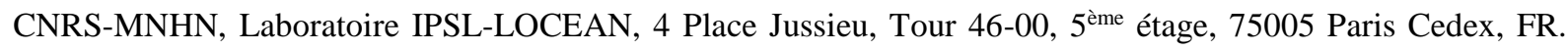
Phone : +33 1480255 35. Fax : +33 1480255 54. E-mail : aline.tribollet@ird.fr

Keywords: Biogenic carbonate dissolution, microborers, euendoliths, coral reefs, ocean acidification, seawater alkalinity

\section{Acknowledgments}

We would like to dedicate this paper to our colleague and friend Marlin Atkinson who passed away in 2013. A.T. and P.C. conceived the experimental design. A.T., P.C. and A.C. collected samples and analysed data. A.T. and P.C. wrote the article and A.C. gave assistance on figure preparations and for formatting. We thank the Plateforme Alizes (IRD Bondy) for SEM access and S. Pyneeandy for her help with measurements of biogenic rates on coral blocks. We thank the Center IRD in Nouméa for its support in the field. Finally, this work was supported by the French Ministry of Ecology (program 'MIDACOR', 2011-2014) and the Institut de Recherche pour le Développement. The funding sponsors had no involvement in the present study development (design, collection, analysis, etc.). 
29 Rising atmospheric $\mathrm{CO}_{2}$ is acidifying the world's oceans affecting both calcification and dissolution processes in coral reefs. Among processes, carbonate dissolution by bioeroding microflora has been overlooked, and especially its impact on seawater alkalinity. To date, this biogeological process was only studied using microscopy or buoyant weight techniques. To better understand its possible effect on seawater alkalinity and thus, on reef carbonate budget, an experiment was conducted under various seawater chemistry conditions $\left(2 \leq \Omega_{\text {arag }} \leq 3.5\right.$ corresponding to $440 \leq \mathrm{pCO} 2(\mu \mathrm{atm}) \leq 940)$ at $25^{\circ} \mathrm{C}$ under night and daylight $(200 \mu \mathrm{mol}$ photons $\mathrm{m}^{-2} \mathrm{~s}^{-1}$ ) with natural microboring communities colonizing dead coral blocks (New Caledonia). Both the alkalinity anomaly technique and microscopy methods were used to study the activity of those communities dominated by the chlorophyte Ostreobium sp. Results show that (1) the amount of alkalinity released in seawater by such communities is significant and vary between $12.8 \pm 0.7$ at $\Omega_{\text {Arag }} \sim 2$ and $5.6 \pm 0.4 \mathrm{mmol} \mathrm{CaCO}_{3} \mathrm{~m}^{-2} \mathrm{~d}^{-1}$ at $\Omega_{\mathrm{Arag}} \sim 3-3.5$ considering a 12:12 photoperiod, (2) although dissolution is higher at night ( $80 \%$ vs $20 \%$ during daylight), the process can occur under a significant photosynthetic activity, and (3) the process is greatly stimulated when an acidity threshold is reached $\left(\mathrm{pCO}_{2} \geq 920 \mu\right.$ atm vs current conditions at constant light intensity). We show that carbonate dissolution by microborers is a major biogeochemical process that could dissolve a large part of the carbonates deposited by calcifying organisms under ocean acidification. 


\section{Introduction}

Atmospheric carbon dioxide partial pressure $\left(\mathrm{pCO}_{2}\right)$ is rising exponentially due to burning of fossil fuels and changing land-use, and is expected to double ( 750 $\mu$ atm) by 2100 (Stocker et al. 2013). Thirty to $50 \%$ of anthropogenic $\mathrm{CO}_{2}$ emissions are presently absorbed by the world's oceans, decreasing seawater pH (Sabine et al. 2004; Wu et al. 2018), with a decrease estimated at $0.3-0.4 \mathrm{pH}$-units by 2100 in the worst-case scenario (Caldeira and Wickett 2003; Stocker et al. 2013). As a consequence, the saturation state of surface seawater $(\Omega)$ with respect to calcium carbonate minerals $\left(\mathrm{CaCO}_{3}\right)$ will also decrease, impacting calcification rates of marine organisms (Orr et al. 2005; Guinotte and Fabry 2008), and increasing rates of

carbonate dissolution (Feely et al. 2004; Tribollet et al. 2009; Krumins et al. 2013; Enochs et al. 2016; Stubler and Peterson 2016; Trnovsky et al. 2016; Schönberg et al. 2017; Eyre et al. 2018).

A recent model (Cyronak et al. 2014) shows that the average $\mathrm{pCO}_{2}$ may have increased faster in coral reef ecosystems than in the open ocean $(\sim 3.5$-fold $)$ over the past 20 years due to additional anthropogenic disturbances (e.g. nutrient and organic matter inputs), putting these carbonate ecosystems even more at risk under ocean acidification (Andersson and MacKenzie 2012). Recent studies highlighted the negative effect of ocean acidification (combined or not with a rise in seawater temperature) on growth, abundance and calcification rates of the main reef framebuilders, i.e. corals and calcifying algae (Langdon and Atkinson 2005; Kuffner et al. 2007; Pandolfi et al. 2011; Comeau et al. 2015; Johnson et al. 2014). Although the same trend is usually observed at the global reef scale, the relationship between community calcification and aragonite saturation state varies dramatically from one location to the next (Yates and Halley 2006; Silverman et al. 2007; Shamberger et al. 2011; Chan and Connolly 


\section{.}

2012; Falter et al. 2012; Shaw et al. 2012). Pandolfi et al. (2011) suggested that the largest variations among ecosystems could result from differences in sediment composition; some being enriched in Mg-calcite are thus the first to be dissolved (see also Yates and Halley 2006). Dissolution however includes several processes: chemical dissolution resulting from environmental conditions (i.e. properties of the bulk of seawater), metabolic dissolution driven by bacteria through the remineralisation of organic matter, and metabolic dissolution driven by bioeroders such as microborers and sponges, also called biogenic dissolution (Tribollet et al. 2009; Schönberg et al. 2017). Rates of dissolution and resulting fluxes are therefore highly variable in shallow water sediments and affected by a number of factors other than aragonite saturation state, which may explain part of those variations (Milliman 1993; Pandolfi et al. 2011; Andersson and Gledhill 2013; Eyre et al. 2014).

Biogenic dissolution due to microborers (or euendoliths; see definition Golubic et al. 1981) received little attention as compared to calcification processes, although microborers which comprise cyanobacteria, algae and fungi, are efficient agents of carbonate dissolution, especially the chlorophyte of the genus Ostreobium which dominates mature communities (Tribollet 2008a; Grange et al. 2015). The penetration of microborers into carbonates, both in dead and live substrates such as corals, is an active process (see for instance Figure 1d in Tribollet et al. 2011) and results in $\mathrm{CaCO}_{3}$ dissolution as these organisms leave traces (galleries or microborings) which conform perfectly to the shape of their filaments (Radtke 1993; Tribollet 2008b; Wisshak et al. 2011). The known rates of biogenic dissolution by these communities at ambient $\mathrm{pCO}_{2}$ measured using microscopy or buoyant weight techniques are on average 0.1-1.8 $\mathrm{mmol} \mathrm{m}^{-2} \mathrm{~h}^{-1}$ in dead coral skeletons (Tribollet 2008a; Reyes-Nivia et al. 2013). These values fall within the range provided for net dissolution in coral rubble reported 
102 by Andersson and Gledhill (2013) suggesting that microborers could be the main agents of

103 carbonate dissolution in such substrates.

105 To date however, it is not known whether the metabolic activity of microborers can contribute

106 significantly to an increase of bulk alkalinity of seawater and therefore, if it can buffer the

107 system. Indeed, the process of biogenic dissolution has always been studied using microscopy

108 or buoyant weight techniques. Biogenic dissolution can either increase seawater alkalinity

109 (net dissolution is measured) or not if calcium carbonate is re-precipitated inside substrates or

110 at their surfaces (micritization process; Kobluk and Risk 1977; Nothdurft and Webb 2009).

111 Intuitively, it is difficult to imagine net carbonate dissolution by microborers (or euendoliths)

112 during daylight as they are mostly photosynthetic micro-organisms rising $\mathrm{pH}$ (Vooren 1981;

113 Tribollet et al. 2006), which is thermodynamically not favourable to dissolution.

115 The goals of the present study were thus to determine if (1) biogenic dissolution by natural 116 mature microboring communities dominated by Ostreobium sp. significantly increases

117 seawater alkalinity, (2) if so, when during the daily cycle, and (3) whether ocean acidification

118 stimulates this potential release of alkalinity as recent studies performed under controlled 119 conditions and in situ showed that rising $\mathrm{pCO}_{2}$ increase rates of gross biogenic dissolution,

120 i.e. rates of $\mathrm{CaCO}_{3}$ removed by microborers when measured by microscopy and buoyant

121 weight techniques (Tribollet et al. 2009; Reyes-Nivia et al. 2013; Enochs et al. 2016). To

122 achieve these objectives, we carried out an experiment with blocks of dead corals (Porites

123 lobata) naturally colonized by mature microboring communities from New Caledonia. Blocks

124 were maintained under fully controlled conditions to test the effects of rising $\mathrm{pCO}_{2}$ (decrease 125 of $\Omega_{\text {arag }}$ ) on microborer metabolism. The metabolic activity of microborers 126 (photosynthesis/respiration and carbonate dissolution/precipitation) was determined by 
respirometry and the alkalinity anomaly technique. Samples were also studied using

128 microscopy techniques (gross biogenic dissolution) in order to compare rates of biogenic

129 dissolution obtained with the alkalinity anomaly technique (net biogenic dissolution).

\section{Methods}

\subsection{Experimental design}

134 Experimental blocks of dead coral skeleton $(7 \times 5 \times 5 \mathrm{~cm})$ were cut in the center of a massive

135 live coral colony of Porites lobata collected in the lagoon of New Caledonia at Larégnère

136 reef. This location was chosen to collect large, healthy, massive colonies of Porites to prepare experimental blocks (with negligible initial bioerosion). Blocks were bleached (at least one week), rinsed with fresh water (one week) and then dried (two weeks). In October 2009, 6 blocks were fixed on an aluminium grid with bolts and nuts to be laid at $14 \mathrm{~m}$ depth on the

140 reef of Casy (Southern lagoon of Grande Terre, New Caledonia). This reef was selected to

141 study biogenic dissolution under nearshore conditions. Water surrounding Casy is regularly

142 impacted by terrigeneous inputs rendering visibility underwater very limited (0-4 m). After 1

143 year of colonization by epilithic and endolithic organisms (2009-2010), 3 colonized blocks

144 were randomly collected and brought back to the Institut de Recherche pour le

145 Développement in Nouméa (2 h transport) and put in a 1501 tank. The tank was filled with

146 filtered seawater (Whatman GF/C) pumped at Casy. A 12:12 h daylight to night photoperiod

147 was applied with a light intensity of $200 \mu \mathrm{mol}$ photons $\mathrm{m}^{2} \mathrm{~s}^{-1}$ delivered by two Solar simulator

148 Arrays (Tailored lighting). A heater-chiller provided a constant temperature in the tank (25.2

$\left.149 \pm 0.1^{\circ} \mathrm{C}\right)$. Three different saturation states were tested, $\Omega_{\text {Arag }}=2,3$ and 3.5 with a constant 150 seawater alkalinity $\mathrm{A}_{\mathrm{T}}$ (see initial conditions in Table 1$)$, by mixing $\mathrm{HCl}\left(0.1 \mathrm{~mol} \mathrm{l}^{-1}\right)$ and 
$151 \mathrm{NaHCO}_{3}\left(1 \mathrm{~mol} \mathrm{l}^{-1}\right)$ to seawater, simulating a realistic $\mathrm{CO}_{2}$ enrichment scenario (Chauvin et 152 al. 2011).

153 Prior incubation, colonized blocks were gently brushed to remove all epiliths, including 154 calcifying organisms such as crustose coralline algae (Fig. 1A). Blocks were then incubated 155 for $2 \mathrm{~h}$ in the morning (daylight conditions) and in the evening (night conditions) using 1.61 156 incubation chambers submerged in the tank. A battery-driven magnetic stirrer homogenized 157 seawater inside chambers. In addition, 3 controls of seawater and 3 controls of bleached 158 uncolonized blocks were incubated in the same conditions per incubation. At the end of the 159 incubations, seawater samples were collected to measure $\mathrm{A}_{\mathrm{T}}$ and $\mathrm{pH}_{\mathrm{T}}$ according to the 160 methods described below. The mean value obtained for seawater controls at the beginning of 161 the incubations was used as the initial condition in the incubation chambers. No metabolic 162 activity was recorded on seawater controls during incubations. The mean value obtained for 163 bleached uncolonized blocks at the end of incubations was used to correct dissolution rates of 164 colonized blocks. Indeed slightly significant rates of $\mathrm{CaCO}_{3}$ precipitation were measured 165 under current conditions ('nucleus' effect of bleached coral blocks in a super-saturated 166 seawater; see Morse 1983).

167 At the end of the experiment, the 3 colonized blocks were preserved in a seawater buffered 168 formaldehyde solution (3\%) prior microscopy analysis in the laboratory. Using microscopy 169 techniques similar to those used by Tribollet et al. (2009), gross rates of biogenic dissolution 170 were quantified (microdensity and porosity of the coral colony skeleton were $2.58 \pm 0.06$ $171 \mathrm{~g} \mathrm{~cm}^{-3}$ and $53 \pm 3 \%$, respectively). Rates were expressed in $\mathrm{kg} \mathrm{CaCO}_{3} \mathrm{~m}^{-2} \mathrm{y}^{-1}$ or $172 \mathrm{mmol} \mathrm{CaCO}_{3} \mathrm{~m}^{-2} \mathrm{~d}^{-1}$ for comparison with net dissolution rates obtained with the alkalinity 173 anomaly technique. The block surface area used in the calculation was the surface area 174 exposed to light i.e. the surface area of 5 colonized sides $\left(0.0155 \mathrm{~m}^{2}\right)$. 
175 As in previous studies of bioerosion, especially microbioerosion, a limited number of samples

176 was used (see Chazottes et al. 1995; Tribollet et al. 2006; Tribollet 2008a; Grange et al. 2015;

177 Enochs et al. 2016). The 3 large coral blocks were however representative of parts of reef

178 framework (i.e. pavement and coral rubble colonized by epilithic and endolithic communities;

179 Chazottes et al. 1995; Adey 1998) and allowed natural microboring communities to develop

180 with their usual patchiness distribution (Tribollet and Golubic 2005). To quantify gross rates

181 of biogenic dissolution, 3 independent pieces of coral skeleton $(1 \mathrm{~cm} \mathrm{x} 0.5 \mathrm{~cm} \mathrm{x} 1 \mathrm{~cm}$ in 182 depth) were collected at the top surface of each block (i.e. surface facing light on the reef).

183 Each piece was then cut in half perpendicular to the top surface. One half was used for SEM 184 observations and quantification of the bioeroded surface area by microborers (see Tribollet 185 and Golubic 2005), while the other half was used to prepare several thin sections (at least 5)

186 to measure the mean depth of penetration of alive microboring filaments ( $\mathrm{n}>100$ 187 measurements per piece; see definition in Tribollet et al. 2009). A total of 9 independent 188 pieces of blocks were therefore studied to quantify the average gross biogenic dissolution rate 189 under ambient $\mathrm{pCO}_{2}$ conditions.

\subsection{Seawater chemistry analysis}

192 Saturated mercuric chloride was added to the seawater samples to prevent biological activity

193 [46]. Potentiometric determination of $\mathrm{pH}_{\mathrm{T}}$ was performed using Tris/HCl and 2194 aminopyridine/ $\mathrm{HCl}$ buffers in synthetic seawater to calibrate the electrode (Dickson et al. 195 2007). Measurements of $\mathrm{pH}_{\mathrm{T}}$ were performed at $25.0 \pm 0.1^{\circ} \mathrm{C}$ using a Radiometer TIM865 196 titrator with combined $\mathrm{pH}$ electrode $\mathrm{pHC} 2401-8$ and a thermostat bath. $\mathrm{A}_{\mathrm{T}}$ samples were 197 filtered through Whatman GF/F prior analysis. Potentiometric titration of $\mathrm{A}_{\mathrm{T}}$ was performed 198 using $0.01 \mathrm{~mol} \mathrm{l}^{-1} \mathrm{HCl}$ in $\mathrm{NaCl}$ to approximate the ionic strength of seawater. Each day of $\mathrm{A}_{\mathrm{T}}$ 199 measurements, Certified Reference Material from the laboratory of A. Dickson (Scripps 
Institution of Oceanography) was titrated to determinate the acid titrant concentration. $\mathrm{A}_{\mathrm{T}}$ was

201 calculated in triplicate from the second inflection point of the titration curve obtained using an automatic titration of $25 \mathrm{ml}$ seawater sample. The precision of the analysis based on triplicate measurements ( \pm 1 standard deviation) was typically $\pm 2 \mu$ equiv $1^{-1}$.

204 Measured $\mathrm{pH}_{\mathrm{T}}$ and $\mathrm{A}_{\mathrm{T}}$ were used to calculate the other $\mathrm{CO}_{2}$ chemistry parameters with the 205 software CO2SYS (Pierrot et al. 2006). In New Caledonia, phosphate and silicate 206 concentrations were 0.03 and $3.1 \mu \mathrm{mol} \mathrm{l}^{-1}$, respectively. Conversions between $\mu \mathrm{mol} \mathrm{l}^{-1}$ and $\mu \mathrm{mol} \mathrm{kg}{ }^{-1}$ were performed based on seawater salinity $(\mathrm{S}=35.33)$ and temperature.

\subsection{Net dissolution and organic carbon metabolism calculation}

210 Net dissolution rates $(\mathrm{G})$, expressed in $\mathrm{mmol} \mathrm{CaCO}_{3} \mathrm{~m}^{-2} \mathrm{~h}^{-1}$ were calculated according to the 211 following equation:

(1) $\mathrm{G}=\left(1 / 2 \Delta \mathrm{A}_{\mathrm{T}} \times\right.$ seawater volume $) /($ substrate surface area $\times$ time $)$

where $G$ is positive when net dissolution occurs, $\Delta A_{T}$ is the difference in alkalinity between

214 two measurements (final $\mathrm{A}_{\mathrm{T}}$ minus initial $\mathrm{A}_{\mathrm{T}}$ ), seawater volume is the volume of the 215 incubation chambers, substrate surface area is the surface of the 5 sides of blocks exposed to 216 light, and time was the duration of the incubation.

218 Net organic carbon metabolism (NP), expressed in $\mathrm{mmol} \mathrm{C} \mathrm{m}^{-2} \mathrm{~h}^{-1}$ was calculated according 219 to the following equation:

(2) $\mathrm{NP}=((\Delta \mathrm{DIC} \times$ seawater volume $) /($ substrate surface area $\times$ time $))-\mathrm{G}$

221 where $N P$ is the rate of net photosynthesis during daylight (negative value, although for 222 simplicity it will be presented as positive in the results) or the rate of night respiration 223 (positive value) and $\triangle D I C$ is the difference in DIC between two measurements (final DIC 224 minus initial DIC). The other symbols are as defined in Eq. 1. 
226 Daily net dissolution (in $\mathrm{mmol} \mathrm{CaCO}_{3} \mathrm{~m}^{-2} \mathrm{~d}^{-1}$ ) was obtained by multiplying the average of daylight and night rates (in mmol $\mathrm{CaCO}_{3} \mathrm{~m}^{-2} \mathrm{~h}^{-1}$ ) by 24 . Daily respiration (in mmol $\mathrm{C} \mathrm{m}^{-2} \mathrm{~d}^{-1}$ ) was calculated as 24 times the night respiration rate (in $\mathrm{mmol} \mathrm{C} \mathrm{m}^{-2} \mathrm{~h}^{-1}$ ). Daily gross production (in $\mathrm{mmol} \mathrm{C} \mathrm{m}^{-2} \mathrm{~d}^{-1}$ ) was calculated by adding night respiration and net 230 photosynthesis (both positive, in $\mathrm{mmol} \mathrm{C} \mathrm{m}^{-2} \mathrm{~h}^{-1}$ ) and multiplying by 12 .

\subsection{Statistical analysis}

Statistical tests were performed using STATISTICA 7.1 (Statsoft). Data were tested for 234 homogeneity of variances (Levene test) prior to variance analysis and met this requirement. Differences among treatments were tested using a 2-way ANOVA. Means are reported \pm SE.

\section{Results}

240 Observations under light microscopy confirmed that dead coral blocks were colonized by mature communities of microborers dominated by the chlorophyte of the genus Ostreobium

242 (Fig. 1B). In addition to Ostreobium, filaments of the euendolithic cyanobacterium 243 Plectonema terebrans were observed (in abundance) as well as rare fungal hyphae. Coral 244 blocks were covered mainly by large thalli of the brown alga Lobophora variegata and the 245 red alga Peyssonnelia sp. Some green turf puffs were also observed with entrapped sediments, 246 as well as a few encrusting coralline algae. No traces of boring polychaetes were observed 247 while a few traces of grazing were observed on block surfaces. These substrates were thus 
representative of dead coral skeletons recently exposed to bioerosion in shallow reefs $(<15 \mathrm{~m}$ depth) (Chazottes et al. 1995; Tribollet 2008a; Grange et al. 2015).

At constant light and temperature (Table 1), $\mathrm{CaCO}_{3}$ dissolution measured by the alkalinity anomaly technique was simultaneously affected by light (daylight vs. night conditions: $\mathrm{p}<$ 0.0003 ) and $\Omega_{\text {Arag }}\left(\mathrm{p}<0.02\right.$ ), with no interaction between the two factors (Fig. 2). $\mathrm{CaCO}_{3}$ dissolution was higher at night than at $200 \mu \mathrm{mol}$ photons $\mathrm{m}^{-2} \mathrm{~s}^{-1}$ (on average $8.4 \pm 1.1 \mu \mathrm{mol}$ $\mathrm{CaCO}_{3}$ block $^{-1} \mathrm{~h}^{-1}$ and $1.9 \pm 1.1 \mu \mathrm{mol} \mathrm{CaCO}_{3}$ block $^{-1} \mathrm{~h}^{-1}$, respectively) (Fig. 2). $\mathrm{CaCO}_{3}$ dissolution was the highest at $\Omega_{\text {Arag }} \sim 2$ with an average of $8.3 \pm 1.5 \mu \mathrm{mol} \mathrm{CaCO}_{3}$ block $^{-1} \mathrm{~h}^{-1}$ (vs. $3.6 \pm 1.2 \mu \mathrm{mol} \mathrm{CaCO}_{3}$ block $^{-1} \mathrm{~h}^{-1}$ at $\Omega_{\text {Arag }} \sim$ 3-3.5). Besides, the difference in $\mathrm{CaCO}_{3}$ dissolution between night and daylight conditions did not differ significantly among treatments. Taking into account the exposed surface area of the blocks $\left(5\right.$ sides $\left.=155 \mathrm{~cm}^{2}\right)$, 260 the daily $\mathrm{CaCO}_{3}$ dissolution was $12.8 \pm 0.7 \mathrm{mmol} \mathrm{CaCO}_{3} \mathrm{~m}^{-2} \mathrm{~d}^{-1}$ (corresponding to an alkalinity production of $\left.25.6 \pm 1.4 \mathrm{mEq} \mathrm{m}^{-2} \mathrm{~d}^{-1}\right)$ and $5.6 \pm 0.4 \mathrm{mmol} \mathrm{CaCO}_{3} \mathrm{~m}^{-2} \mathrm{~d}^{-1}(11.2 \pm 0.8$ $\left.\mathrm{mEq} \mathrm{m}^{-2} \mathrm{~d}^{-1}\right)$ at $\Omega_{\text {Arag }} \sim 2$ and $\Omega_{\text {Arag }} \sim 3-3.5$, respectively.

Under night conditions, respiration rate was not affected by $\Omega_{\text {Arag }}$ (Fig. 2) and was on average $17.7 \pm 0.8 \mu \mathrm{mol} \mathrm{C}$ block $^{-1} \mathrm{~h}^{-1}$, or $27 \pm 1 \mathrm{mmol} \mathrm{C} \mathrm{m}^{-2} \mathrm{~d}^{-1}$. Similarly, net photosynthesis was the same regardless $\Omega_{\text {Arag }}\left(8.7 \pm 1.5 \mu\right.$ mol C block $^{-1} \mathrm{~h}^{-1}$ on average $)$. Gross production $\left(\mathrm{P}_{\mathrm{g}}\right)$, however, was slightly affected by $\Omega_{\text {Arag }}(\mathrm{p}<0.05)$, with a higher value at $\Omega_{\text {Arag }} \sim 2$ than $\Omega_{\text {Arag }}$ 3-3.5 (24 \pm 2 versus $18 \pm 1 \mathrm{mmol} \mathrm{C} \mathrm{m}^{-2} \mathrm{~d}^{-1,}$ respectively). The $\mathrm{Pg} / \mathrm{R}$ ratio was clearly lower than $1\left(0.89 \pm 0.08\right.$ and $0.67 \pm 0.02$ at $\Omega_{\mathrm{Arag}} \sim 2$ and $\Omega_{\mathrm{Arag}} \sim 3-3.5$, respectively).

271 The mean depth of penetration of alive euendolithic filaments was $1.81 \pm 0.05 \mathrm{~mm}$ and the mean surface area bioeroded at the surface of the blocks was $12.85 \pm 1.1 \%$. The estimated 
273 gross rate of biogenic dissolution using microscopy techniques averaged $0.240 \pm 0.002 \mathrm{~kg} \mathrm{~m}^{-}$

$274{ }^{2} \mathrm{y}^{-1}$, which converts to $7.40 \pm 0.05 \mathrm{mmol} \mathrm{m}^{-2} \mathrm{~d}^{-1}$.

\section{Discussion}

\subsection{Production of alkalinity in seawater by microborers under present conditions}

279 To our knowledge, our experiment is the only study in which dissolution of experimental carbonate substrates colonized by natural microboring communities was simultaneously quantified using microscopy and alkalinity anomaly techniques. Under $200 \mu$ mol photons $\mathrm{m}^{-2}$ $\mathrm{s}^{-1}$ and $\Omega_{\text {Arag }} \sim 3.5$ (similar to $\Omega_{\text {Arag }}$ measured at Ilot Casy during an entire day upon block collection; $3.58 \pm 0.03, \mathrm{n}=14$ ), the photosynthetic activity of endolithic communities was presumably limited by light and/or DIC availability as the $\mathrm{Pg}_{\mathrm{g}} / \mathrm{R}$ ratio was clearly lower than 1 $(0.67 \pm 0.02)$. Although this may have slightly limited the erosive activity of microborers under controlled conditions, the rates of gross biogenic dissolution (microscopy technique) and net dissolution (alkalinity anomaly technique) were of the same order of magnitude at $\Omega_{\text {Arag }}$ 3-3.5 (7.4 $\pm 0.1 \mathrm{mmol} \mathrm{CaCO}_{3} \mathrm{~m}^{-2} \mathrm{~d}^{-1}$ versus $5.6 \pm 0.4 \mathrm{mmol} \mathrm{m}^{-2} \mathrm{~d}^{-1}$, respectively). Other processes than the microborer activity, such as denitrification, can increase alkalinity in seawater (Stumm and Morgan 1996) but are likely to be insignificant in most hard substrate situations (Kinsey 1978; Gattuso et al. 1999). High-magnesium calcite is also rarely observed

292 in coral skeletons (Nothdurft et al. 2007), therefore dissolution of this form of carbonates was 293 most probably not involved in the measured dissolution process. Although some bacterial 294 activity at the block surfaces cannot be ruled out, bacterial activity inside blocks was not 295 involved in $\mathrm{CaCO}_{3}$ dissolution as we did not observe random patterns of dissolution on 296 scanning electron microscopy pictures. We thus strongly suggest that alive microboring 
communities in coral blocks were responsible for the bulk of alkalinity production in our 298 experiment.

\subsection{Daily cycle of biogenic dissolution}

301 Surprisingly $20 \%$ of the daily rate of biogenic dissolution was occurring during daylight.

302 Although it seems a paradox to measure simultaneously carbonate dissolution (i.e. release of 303 seawater alkalinity) and photosynthesis, Garcia-Pichel et al. (2010) clearly showed that 304 biogenic dissolution of experimental carbonate substrates by the cultured cyanobacterium $M$. testarum was coupled to the photosynthetic energy production. In our experiment, higher rates

306 of net biogenic dissolution were quantified under night conditions than at $307200 \mu \mathrm{mol}$ photons. $\mathrm{m}^{-2} \cdot \mathrm{s}^{-1}$. The decrease of the interstitial $\mathrm{pH}$ with increasing depth into a 308 Porites cylindrica skeleton colonized mainly by Ostreobium was also particularly important 309 in the dark in Reyes-Nivia et al. (2013)'s study, suggesting that night respiration by 310 microborers could be an important factor involved in $\mathrm{CaCO}_{3}$ dissolution.

\subsection{Effect of ocean acidification on microborer metabolism and alkalinity production}

313 A 33\% increase in gross production was recorded at $\Omega_{\mathrm{Arag}} \sim 2\left(\mathrm{pCO}_{2}\right.$ of $\left.936 \mu \mathrm{atm}\right)$ relative to $314 \Omega_{\mathrm{Arag}} \sim 3-3.5\left(\mathrm{pCO}_{2}\right.$ of 437-570 $\left.\mu \mathrm{atm}\right)$, suggesting that endolithic communities dominated by Ostreobium were limited by DIC availability at $\Omega_{\text {Arag }} \sim 3-3.5$. Photosynthesis limitation at $\Omega_{\text {Arag }} \sim 3-3.5$ was also highlighted by the low $\mathrm{Pg} / \mathrm{R}$ ratio $(0.67 \pm 0.02)$. Although Ostreobium 317 presents carbonic anhydrases (CAs) that may serve as a mechanism to supply inorganic 318 carbon at the required rate for photosynthesis (Shashar and Stambler 1992), it remains unknown if it possesses Carbon Concentrating Mechanisms (CCMs) involving active transport of $\mathrm{HCO}_{3}{ }^{-}$and/or $\mathrm{CO}_{2}$. In general, photosynthetic rates of algae that have CCMs are not carbon limited, at least under most environmental conditions (e.g. Hurd et al. 2009). Some 
species that have CCMs may however, be dependent on $\mathrm{CO}_{2}$ and positively respond to elevated $\mathrm{pCO}_{2}$ at sub-saturating irradiance, because light limitation of active carbon uptake increases reliance on $\mathrm{CO}_{2}$ diffusion (Hepburn et al. 2011).

To the contrary of photosynthesis, night respiration was not affected by acidification (Fig. 2). Most studies to date have reported no or little effect of elevated $\mathrm{CO}_{2}$ on dark respiration rates of macroalgae (e.g. Zou et al. 2011; Noisette et al. 2013). Because the responses to elevated $\mathrm{CO}_{2}$ of respiration and photosynthesis were different in our experiment, $\mathrm{pCO}_{2}$ increase resulted in an increase in the $\mathrm{P}_{\mathrm{g}} / \mathrm{R}$ ratio. Zou et al. (2011) reported that $\mathrm{CO}_{2}$ enrichment decreased the respiratory carbon lost per unit algal biomass in a low-N-grown macroalga, and suggested that $\mathrm{CO}_{2}$ enrichment may thereby enhance carbon sequestration capacity of this organism.

The amount of alkalinity released in seawater doubled at $\Omega_{\text {Arag }} \sim 2$ compared to $\Omega_{\text {Arag }} \sim 3-3.5$ $\left(25.6 \pm 1.4\right.$ and $11.2 \pm 0.8 \mathrm{mEq} \mathrm{m}^{-2} \mathrm{~d}^{-1}$, respectively). Net biogenic dissolution rates did not vary significantly between $\Omega_{\mathrm{Arag}} \sim 3$ and $3.5\left(\mathrm{pCO}_{2}=570\right.$ and $437 \mu$ atm respectively) 338 suggesting that a threshold somewhere between $\Omega_{\text {Arag }} \sim 2$ and 3 must be reached before promoting increased $\mathrm{CaCO}_{3}$ dissolution by microboring communities from New Caledonia.

340 The increase in net biogenic dissolution under elevated $\mathrm{pCO}_{2}$ in New Caledonia confirms the 341 increase of gross biogenic dissolution reported by Tribollet et al. (2009) and Reyes-Nivia et 342 al. (2013) for dead coral skeletons which were exposed during a few months to high $\mathrm{pCO}_{2}$ $343\left(48 \%\right.$ at $750 \mu \mathrm{atm}$ and $46-89 \%$ at $1000 \mu \mathrm{atm}$ relative to ambient $\mathrm{pCO}_{2}$ depending on coral species, respectively). A similar trend was also observed for pioneer euendolithic

345 communities dominated by the chlorophyte Phaeophila sp. under naturally acidified 346 conditions at Maug Island (Mariana Archipelago; Enochs et al. 2016). 
348 Similarly to zooxanthellate boring sponges under high $\mathrm{pCO}_{2}$ (Wisshak et al. 2012), increased

349 biogenic dissolution by microborers could be explained by an enhancement of photosynthetic 350 energy, and/or the lowering of the $\mathrm{pH}$ gradient between ambient seawater and the site of 351 dissolution, thereby lowering the metabolic cost required for $\mathrm{CaCO}_{3}$ dissolution. Providing 352 acidified seawater near the dissolution front of euendolithic filaments could make interstitial 353 water thermodynamically more favourable to chemical dissolution. Changes in extracellular $354 \mathrm{pH}$ have also been shown to directly drive changes in intracellular $\mathrm{pH}$ of some marine 355 microalgae and in turn affect $\mathrm{H}^{+}$gradients and cellular $\mathrm{pH}$ homeostasis (Taylor et al. 2011). 356 That such processes are used at the dissolution front in Ostreobium remains to be determined. 357 Basic knowledge of the process of $\mathrm{CaCO}_{3}$ dissolution is currently lacking to fully understand 358 mechanisms behind Ostreobium response to acidification.

\subsection{Significance of biogenic dissolution in coral reefs}

361 Gross and net rates of biogenic dissolution measured as part of our experiment fall well

362 within the range of gross and net rates of biogenic dissolution reported in the literature for 363 hard dead reef substrates (Table 2). They are also similar to rates quantified on fringing and 364 lagoon reefs (Tribollet 2008a; Tribollet et al. 2009). Interestingly all rates provided in Table 2 365 fall within the range of net dissolution rates provided for various carbonate substrates by 366 Andersson and Gledhill (2013) suggesting that biogenic dissolution by microborers is a major 367 process of carbonate dissolution in coral reefs.

369 Considering all biogenic dissolution rates for hard substrates in Table 2, the average rate is 11 $370 \mathrm{mmol} \mathrm{m}{ }^{-2}$ of reef $\mathrm{d}^{-1}$. This average is assumed to be representative of the process occurring on 371 reefs as it includes rates of biogenic dissolution measured under a full range of biotic and 
abiotic conditions (e.g. light availability and grazing). At the scale of reefs worldwide (surface area of $0.610^{12} \mathrm{~m}^{2}$ including $80 \%$ of sand and $20 \%$ of hard substrates, Milliman 1993) and because microborers can colonize all types of reef carbonates, gross biogenic dissolution is estimated to be $1110^{-3} \times 365 \times 0.2 \times 0.610^{12}=0.510^{12} \mathrm{~mol} \mathrm{CaCO}_{3} \mathrm{y}^{-1}$ in hard substrates (living corals being also colonized by microborers; see Tribollet 2008b). Considering an average gross rate of biogenic dissolution for sediments of $10 \mathrm{mmol} \mathrm{m}^{-2} \mathrm{~d}^{-1}$ (Tudhope and Risk 1985), nearly four times more $\mathrm{CaCO}_{3}$ seems to be dissolved by microborers in sediments than in hard substrates $\left(1.810^{12} \mathrm{~mol} \mathrm{CaCO}^{3} \mathrm{y}^{-1}\right)$. If we consider a net $\mathrm{CaCO}_{3}$ production in coral reefs of $910^{12} \mathrm{~mol} \mathrm{CaCO}_{3} \mathrm{y}^{-1}$ (Milliman 1993), at least $11.310^{12} \mathrm{~mol} \mathrm{CaCO}^{3} \mathrm{y}^{-1}$ (i.e. $910^{12}+0.510^{12}+1.810^{12}$ ) is deposited by calcifying organisms (gross calcification) and at most, $20 \%$ of this produced $\mathrm{CaCO}_{3}$ is probably dissolved by microborers. In the worst case 383 scenario, if we consider a doubling of gross biogenic dissolution rates (Reyes-Nivia et al. 384 2013) and a 40\% decrease in gross carbonate production due to ocean acidification by 2100 (Pandolfi et al. 2011), 2/3 of reef carbonates deposited per year may be dissolved by microborers. In the more optimistic scenario, with only a $50 \%$ increase in $\mathrm{CaCO}_{3}$ gross 387 biogenic dissolution and a $20 \%$ decrease in gross $\mathrm{CaCO}_{3}$ production (e.g. Tribollet et al. 388 2009; Chauvin et al. 2011; Chan and Connolly 2012), 40\% of reef carbonates deposited per 389 year may be dissolved by microborers. Those estimations are very conservative as they do not 390 take into account sediment dissolution resulting from bacterial activity which can be 391 important in some areas (Andersson et al. 2007) and hard carbonate dissolution by boring 392 sponges and bivalves (see review by Schönberg et al. 2017). Although more investigations on 393 the dynamics of the biogenic dissolution process are needed, our estimations strongly suggest 394 that biogenic dissolution of carbonates by microborers should no longer be overlooked and 395 should be considered in reef carbonate biogeochemical models to better predict the fate of 396 coral reefs. 


\section{Conclusions}

399 Results show that microboring communities dominated by the phototrophic microboring chlorophyte of the genus Ostreobium, produce significant amount of alkalinity while 401 penetrating actively into coral skeletons. Daily production is increased by a factor 2 under 402 ocean acidification conditions (i.e. when $\Omega$ decreases from 3-3.5 to 2). Comparisons of net 403 dissolution rates obtained in our study with those in the literature strongly suggest that (i) the biogenic dissolution process resulting from microborer metabolic activity is a major process of carbonate dissolution in coral reefs, and (ii) that it will probably dissolve a large part of reef carbonate deposited per year by the end of the century if human beings maintain their

407 'business as usual' (IPCC 2013). It is not known however, to which extend this process could 408 help maintaining environmental conditions favourable for calcifying organisms ('negative 409 feedback to ocean acidification'). This role could be significant, at least at the microscale as 410 microborers colonize also living calcifying organisms such as corals and crustose coralline 411 algae (Le Campion-Alsumard et al. 1995; Tribollet and Payri 2001). Reyes-Nivia et al. (2014) 412 showed that crustose coralline algae (CCA) heavily colonized by microborers are less 413 sensitive to ocean acidification than CCA that are less infested, suggesting that the negative 414 effects of ocean acidification on CCA calcification are mitigated by microborer 415 photosynthetic activity. It remains unknown however, if this negative feedback of 416 microborers results from their photosynthetic activity (rise of $\mathrm{pH}$ at the microscale) or their 417 dissolution activity (production of alkalinity) or both. We thus urge the scientific community 418 to study the 'potential buffering' effect of microborer metabolic activity on reefs at various 419 spatial scales (micro- to ecosystem scale) and stress the importance to consider the dynamics 420 of carbonate dissolution by microborers to better understand past and future effects of this 421 factor on coral reef biogeomorphology and cycle. 


\section{Data availability}

424 Datasets are available from the corresponding author (aline.tribollet@ird.fr) on reasonable request, while pending to be deposited on the SEANOE repository.

\section{References}

Adey WH (1998) Review. Coral reefs: algal structured and mediated ecosystems in shallow, turbulent, alkaline waters. J Phycol 34:393-406

Andersson AJ, Bates NR, Mackenzie FT (2007) Dissolution of carbonate sediments under

431 rising $\mathrm{pCO}_{2}$ and ocean acidification: observations from Devil's Hole, Bermuda. Aquat

432 Geochem 13:237-264

433 Andersson AJ, Gledhill D (2013) Ocean acidification and coral reefs: effects on breakdown, 434 dissolution, and net ecosystem calcification. Annual Review Mar Sci 5:321-348

435 Andersson AJ, Mackenzie FT (2012) Revisiting four scientific debates in ocean acidification 436 research. Biogeosciences $9: 893-905$

437 Barat R, Montoya T, Borras L, Ferrer J, Seco A (2008) Interactions between calcium 438 precipitation and the polyphosphate-accumulating bacteria metabolism. Water Res 42:3415$439 \quad 3424$

440 Caldeira K, Wickett ME (2003) Oceanography: anthropogenic carbon and ocean pH. Nature $441 \quad 425: 365$

442 Carreiro-Silva M, McClanahan TR, Kiene WE (2005) The role of inorganic nutrients and 443 herbivory in controlling microbioerosion of carbonate substratum. Coral Reefs 24 :214-221

444 Chan N, Connolly SR (2013) Sensitivity of coral calcification to ocean acidification: a 445 meta-analysis. Global Change Biol 19:282-290 
446 Chauvin A, Denis V, Cuet P (2011) Is the response of coral calcification to seawater 447 acidification related to nutrient loading? Coral Reefs 30:911-923

448 Chazottes V, Le Campion-Alsumard T, Peyrot-Clausade M (1995) Bioerosion rates on coral 449 reefs: interactions between macroborers, microborers and grazers (Moorea, French 450 Polynesia). Palaeo3 113:189-198

451 Chazottes V, Le Campion-Alsumard T, Peyrot-Clausade M, Cuet P (2002) The effects of 452 eutrophication-related alterations to coral reef communities on agents and rates of bioerosion 453 (Reunion Island, Indian Ocean). Coral Reefs 21:375-390

454 Comeau S, Carpenter RC, Lantz CA, Edmunds PJ (2015) Ocean acidification accelerates 455 dissolution of experimental coral reef communities. Biogeosciences $12: 365-372$

456 Cyronak T, Schulz KG, Santos IR, Eyre BD (2014) Enhanced acidification of global coral 457 reefs driven by regional biogeochemical feedbacks. Geophys Res Lett 41:5538-5546

458 Dickson AG (1990) Standard potential of the reaction: $\mathrm{AgCl}(\mathrm{s})+1 / 2 \mathrm{H}_{2}(\mathrm{~g})=\mathrm{Ag}(\mathrm{s})+\mathrm{HCl}(\mathrm{aq})$, 459 and the standard acidity constant of the ion $\mathrm{HSO}_{4}{ }^{-}$in synthetic sea water from 273.15 to $460 \quad 318.15$ K. J Chem Thermodynamics 22:113-127

461 Dickson AG, Sabine CL, Christian JR (2007) Guide to best practices for ocean CO2 462 measurements. PICES Spec Pub 3:1-191

463 Enochs IC, Manzello DP, Tribollet, A et al (2016) Elevated colonization of microborers at a 464 volcanically acidified coral reef. PloS One 11:e0159818

465 Eyre BD, Andersson AJ, Cyronak T (2014) Benthic coral reef calcium carbonate dissolution 466 in an acidifying ocean. Nature Climate Change 4:969-976

467 Eyre BD, Cyronak T, Drupp P, De Carlo EH, Sachs JP, Andersson AJ (2018) Coral reefs will 468 transition to net dissolving before end of century. Science 359:908-911 
Falter JL, Lowe RJ, Atkinson MJ, Cuet P (2012) Seasonal coupling and de-coupling of net calcification rates from coral reef metabolism and carbonate chemistry at Ningaloo Reef, Western Australia. J Geophysic Res 117:C05003

472 Feely RA, Sabine CL, Lee K, Berelson W, Kleypas J, Fabry VJ, Millero FJ (2004) Impact of 473 anthropogenic $\mathrm{CO} 2$ on the $\mathrm{CaCO} 3$ system in the oceans. Science 305:362-366

474 Garcia-Pichel F, Ramírez-Reinat E, Gao Q (2010) Microbial excavation of solid carbonates 475 powered by P-type ATPase-mediated transcellular $\mathrm{Ca}^{2+}$ transport. PNAS 107:21749-21754

476 Gattuso JP, Allemand D, Frankignoulle M (1999) Photosynthesis and calcification at cellular, 477 organismal and community levels in coral reefs: a review on interactions and control by 478 carbonate chemistry. Amer Zool 39:160-183

479 Golubic S, Friedmann I, Schneider J (1981) The lithobiontic ecological niche, with special 480 reference to microorganisms. J Sediment Res 51:475-478

481 Grange JS, Rybarczyk H, Tribollet A (2015) The three steps of the carbonate biogenic 482 dissolution process by microborers in coral reefs (New Caledonia). Environmen Sci Pollut 483 Res 22:13625-13637

484 Guinotte JM, Fabry VJ (2008) Ocean acidification and its potential effects on marine 485 ecosystems. Annals of the New York Academy of Sciences 1134:320-342

486 Hepburn CD, Pritchard DW, Cornwall CE, McLeod RJ, Beardall J, Raven JA, Hurd CL 487 (2011) Diversity of carbon use strategies in a kelp forest community: implications for a high $488 \mathrm{CO}_{2}$ ocean. Global Change Biol 17:2488-2497

489 Hoskin CM, Reed JK, Mook DH (1986) Production and off-bank transport of carbonate 490 sediment, Black Rock, southwest Little Bahama Bank. Mar Geol 73 :125-144

491 Hurd CL, Hepburn CD, Currie KI, Raven JA, Hunter KA (2009) Testing the effects of ocean 492 acidification on algal metabolism: considerations for experimental designs. J Phycol 45:1236$493 \quad 1251$ 
Johnson MD, Price NN, Smith JE (2014) Contrasting effects of ocean acidification on tropical

495 fleshy and calcareous algae. PeerJ 2:e411

496 Kinsey DW (1978) Productivity and calcification estimates using slack-water periods and

497 field enclosures. In: Stoddart DR, Johannes RE (eds) Monographs on oceanographic 498 methodology, Coral reefs: research methods. UNESCO, pp 439-468.

499 Krumins V, Gehlen M, Arndt S, Cappellen PV, Regnier P (2013) Dissolved inorganic carbon 500 and alkalinity fluxes from coastal marine sediments: model estimates for different shelf 501 environments and sensitivity to global change. Biogeosciences 10:371-398

502 Kuffner IB, Andersson AJ, Jokiel PL, Ku'ulei SR, Mackenzie FT (2008) Decreased 503 abundance of crustose coralline algae due to ocean acidification. Nature Geoscience 1:114

504 Kobluk DR, Risk MJ (1977) Calcification of exposed filaments of endolithic algae, micrite 505 envelope formation and sediment production. J Sediment Res 47:517-528

506 Langdon C, Atkinson MJ (2005) Effect of elevated pCO2 on photosynthesis and calcification 507 of corals and interactions with seasonal change in temperature/irradiance and nutrient 508 enrichment. J Geophysic Res 110:C09S07

509 Le Campion-Alsumard T, Golubic S, Hutchings PA (1995a) Microbial endoliths in skeletons 510 of live and dead corals: Porites lobata (Moorea, French Polynesia). Mar Ecol Progress Ser $511 \quad 117: 149-157$

512 Milliman JD (1993) Production and accumulation of calcium carbonate in the ocean: budget 513 of a nonsteady state. Global Biogeochem Cycles 7:927-957

514 Morse JW (1983) The kinetics of calcium carbonate dissolution and precipitation. Rev 515 Mineral Geochem 11:227-264

516 Noisette F, Duong G, Six C, Davoult D, Martin S (2013) Effects of elevated $\mathrm{pCO}_{2}$ on the 517 metabolism of a temperate rhodolith Lithothamnion corallioides grown under different 518 temperatures. J Phycol 49:746-757 
519 Nothdurft LD, Webb GE (2009) Earliest diagenesis in scleractinian coral skeletons:

520 implications for palaeoclimate-sensitive geochemical archives. Facies 55 :161-201

521 Nothdurft LD, Webb GE, Bostrom T, Rintoul L (2007) Calcite-filled borings in the most 522 recently deposited skeleton in live-collected Porites (Scleractinia): implications for trace 523 element archives. Geochim Cosmochim Acta 71:5423-5438

524 Orr JC, Fabry VJ, Aumont O et al (2005) Anthropogenic ocean acidification over the twenty525 first century and its impact on calcifying organisms. Nature 437: 681-686

526 Pandolfi JM, Connolly SR, Marshall DJ, Cohen AL (2011) Projecting coral reef futures under 527 global warming and ocean acidification. Science 333:418-422

528 Pierrot D, Lewis E, Wallace DWR (2006) MS Excel program developed for $\mathrm{CO}_{2}$ system 529 calculations. ORNL/CDIAC-105 Carbon Dioxide Information Analysis Center

530 Radtke G (1993) The distribution of microborings in molluscan shells from recent reef 531 environments at Lee Stocking Island, Bahamas. Facies $29: 81-92$

532 Ramirez-Reinat EL, Garcia-Pichel F (2012) Prevalence of $\mathrm{Ca}^{2+}$-ATPase-mediated carbonate 533 dissolution among cyanobacterial euendoliths. Appl Environ Microbiol 78:7-13

534 Reyes-Nivia C, Diaz-Pulido G, Dove S (2014) Relative roles of endolithic algae and 535 carbonate chemistry variability in the skeletal dissolution of crustose coralline algae. 536 Biogeosciences 11:4615-4626

537 Reyes-Nivia C, Diaz-Pulido G, Kline D, Guldberg OH, Dove S (2013) Ocean acidification 538 and warming scenarios increase microbioerosion of coral skeletons. Global Change Biol $539 \quad 19: 1919-1929$

540 Roy RN, Roy LN, Vogel KM et al (1993) The dissociation constants of carbonic acid in 541 seawater at salinities 5 to 45 and temperatures 0 to $45^{\circ} \mathrm{C}$. Mar Chem 44:249-267

542 Sabine CL, Feely RA, Gruber N et al (2004) The oceanic sink for anthropogenic $\mathrm{CO}_{2}$. Science $543 \quad 305: 367-371$ 
544 Schönberg CH, Fang JK, Carreiro-Silva M, Tribollet A, Wisshak M (2017) Bioerosion: the 545 other ocean acidification problem. ICES J Mar Sci 74:895-925

546 Shamberger KEF, Feely RA, Sabine CL et al (2011) Calcification and organic production on

547 a Hawaiian coral reef. Mar Chem 127:64-75

548 Shashar N, Stambler N (1992) Endolithic algae within corals-life in an extreme environment.

549 JEMBE 163:277-286

550 Shaw EC, McNeil BI, Tilbrook B (2012) Impacts of ocean acidification in naturally variable 551 coral reef flat ecosystems. J Geophys Res 117 :C03038

552 Silverman J, Lazar B, Erez J (2007) Community metabolism of a coral reef exposed to 553 naturally varying dissolved inorganic nutrient loads. Biogeochemistry 84 :67-82

554 Stocker TF, Qin D, Plattner GK et al (2013) Technical summary. In: Climate change 2013: 555 the physical science basis. Contribution of Working Group I to the Fifth Assessment Report 556 of the Intergovernmental Panel on Climate Change. Cambridge, UK and New York, NY, 557 USA: Cambridge University Press, pp 33-115

558 Stubler AD, Peterson BJ (2016) Ocean acidification accelerates net calcium carbonate loss in 559 a coral rubble community. Coral Reefs 35:795-803

560 Stumm W, Morgan JJ (1996) Aquatic chemistry: chemical equilibria and rates in natural 561 waters, New York, NY, USA: John Wiley \& Sons

562 Taylor AR, Chrachri A, Wheeler G, Goddard H, Brownlee C (2011) A voltage-gated $\mathrm{H}^{+}$ 563 channel underlying $\mathrm{pH}$ homeostasis in calcifying coccolithophores. PLoS Biology $564 \quad 9: \mathrm{e} 1001085$

565 Tribollet A (2008a) Dissolution of dead corals by euendolithic microorganisms across the 566 northern Great Barrier Reef (Australia). Microbial Ecol 55:569-580 
Tribollet A (2008b) The boring microflora in modern coral reef ecosystems: a review of its roles. In: Wisshak M, Tapanila L (eds) Current Developments in Bioerosion. Berlin, Heidelberg: Springer, pp 67-94

Tribollet, A., Godinot, C., Atkinson, M., \& Langdon, C. (2009). Effects of elevated pCO2 on dissolution of coral carbonates by microbial euendoliths. Global Biogeochem Cycles 23(3):GB3008

Tribollet A, Golubic S (2005) Cross-shelf differences in the pattern and pace of bioerosion of experimental carbonate substrates exposed for 3 years on the northern Great Barrier Reef, Australia. Coral Reefs 24:422-434

Tribollet A, Golubic S, Radtke G, Reitner J (2011) On microbiocorrosion. In: Reitner J, Queric N-V, Arp G (eds) Advances in Geobiology of Stromatolite Formation, Lecture Notes in Earth Sciences, 131:265-276, Berlin, Heidelberg: Springer

Tribollet A, Langdon C, Golubic S, Atkinson M (2006) Endolithic microflora are major primary producers in dead carbonate substrates of Hawaiian coral reefs. J Phycol 42:292-303 Tribollet A, Payri C (2001) Bioerosion of coralline alga Hydrolithon onkodes by microborers in the coral reefs of Moorea French Polynesia. Oceanologica Acta 24:329-342

Trnovsky D, Stoltenberg L, Cyronak T, Eyre BD (2016) Antagonistic effects of ocean acidification and rising sea surface temperature on the dissolution of coral reef carbonate sediments. Frontiers in Marine Science. https://doi: 10.3389/fmars.2016.00211

Tudhope AW, Risk MJ (1985) Rate of dissolution of carbonate sediments by microboring organisms, Davies Reef, Australia. J Sediment Res 55:440-447

Vogel K, Gektidis M, Golubic S, Kiene WE, Radtke G (2000) Experimental studies on microbial bioerosion at Lee Stocking Island, Bahamas and One Tree Island, Great Barrier Reef, Australia: implications for paleoecological reconstructions. Lethaia 33:190-204 
591 Vooren CM (1981) Photosynthetic rates of benthic algae from the deep coral reef of Curacao.

592 Aquatic Botany $10: 143-159$

593 Wisshak M, Schönberg CH, Form A, Freiwald A (2012) Ocean acidification accelerates reef 594 bioerosion. PloS One 7:e45124

595 Wisshak M, Tribollet A, Golubic S, Jakobsen J, Freiwald A (2011) Temperate bioerosion: 596 ichnodiversity and biodiversity from intertidal to bathyal depths (Azores). Geobiology 9:492$597 \quad 520$

598 Wu H, Dissard D, Douville E, Blamart D, Bordier L, Tribollet A, Le Cornec F, Pons-Branchu

599 E, Dapoigny A, Lazareth CE (2018) Surface ocean pH variations since 1689 CE and recent 600 ocean acidification in the tropical South Pacific. Nature Communications. 9:2543. 601 htpps://doi:10.1038/s41467-018-04922-1

602 Yates, K. K., \& Halley, R. B. (2006) $\mathrm{CO}_{3}{ }^{2-}$ concentration and $\mathrm{pCO}_{2}$ thresholds for 603 calcification and dissolution on the Molokai reef flat, Hawaii. Biogeosciences Discussions, $604 \quad 3: 123-154$

605 Zou D, Gao K, Luo H (2011) Short- and long-term effects of elevated $\mathrm{CO}_{2}$ on photosynthesis 606 and respiration in the marine macroalga Hizikia fusiformis (Sargassaceae, phaeophyta) grown 607 at low and high N supplies. J Phycol 47:87-97

608 
611 Table 1. Initial seawater chemistry conditions of the experiment (mean $\pm \mathrm{SD}$ ).

612

\begin{tabular}{llllllll}
\hline & & $\begin{array}{l}\mathrm{T} \text { in situ } \\
\left({ }^{\circ} \mathrm{C}\right)\end{array}$ & $\mathrm{pH}_{\mathrm{T}}$ & $\begin{array}{l}\mathrm{A}_{\mathrm{T}} \\
\left(\mu \mathrm{mol} \mathrm{kg}{ }^{-1}\right)\end{array}$ & $\begin{array}{l}\mathrm{DIC} \\
\left(\mu \mathrm{mol} \mathrm{kg}^{-1}\right)\end{array}$ & $\begin{array}{l}\mathrm{pCO}_{2} \\
(\mu \mathrm{atm})\end{array}$ & $\Omega_{\text {Arag }}$ \\
\hline$\Omega_{\text {Arag }}=2$ & night & 25.2 & $7.740 \pm 0.002$ & $2304 \pm 1$ & $2143 \pm 1$ & $919 \pm 5$ & $2.08 \pm 0.01$ \\
& daylight & 25.2 & $7.725 \pm 0.002$ & $2303 \pm 2$ & $2149 \pm 1$ & $954 \pm 4$ & $2.02 \pm 0.01$ \\
$\Omega_{\text {Arag }}=3$ & night & 25.2 & $7.921 \pm 0.003$ & $2320 \pm 1$ & $2069 \pm 2$ & $568 \pm 4$ & $2.97 \pm 0.01$ \\
& daylight & 25.2 & $7.919 \pm 0.003$ & $2322 \pm 1$ & $2072 \pm 2$ & $571 \pm 4$ & $2.97 \pm 0.01$ \\
$\Omega_{\text {Arag }}=3.5$ & night & 25.3 & $8.010 \pm 0.002$ & $2296 \pm 1$ & $1997 \pm 1$ & $438 \pm 2$ & $3.46 \pm 0.01$ \\
& daylight & 25.2 & $8.012 \pm 0.001$ & $2297 \pm 1$ & $1996 \pm 1$ & $436 \pm 1$ & $3.48 \pm 0.01$ \\
\hline
\end{tabular}

$613 \mathrm{pH}_{\mathrm{T}}$ (total hydrogen ion concentration scale) and total alkalinity $\left(\mathrm{A}_{\mathrm{T}}\right.$, in units of $\mu$ equiv kg $\mathrm{kg}^{-1}$ ) were used to

614 calculate the other $\mathrm{CO}_{2}$ chemistry parameters with the software $\mathrm{CO}_{2}$ Sys (Pierrot et al., 2006): dissolved

615 inorganic carbon (DIC), partial pressure of $\mathrm{CO}_{2}\left(\mathrm{pCO}_{2}\right)$ and aragonite saturation state $\left(\Omega_{\text {Arag }}\right)$, using Roy et al.

616 (1993) values for carbonic acid constants $\mathrm{K}_{1}$ and $\mathrm{K}_{2}$, and $\mathrm{K}_{\mathrm{SO} 4}$ as determined by Dickson (1990)

617

618

619

620

621

622

623

624

625

626 
628 Table 2. Rates of biogenic dissolution from our study and from literature at ambient $\mathrm{pCO}_{2}$, in 629 mmol $\mathrm{CaCO}_{3}$ dissolved per $\mathrm{m}^{2}$ per day. Rates from literature where converted, when 630 necessary, using microdensity and porosity of coral skeletons according to Tribollet et al. 631 (2009). Here, square meters refer to $\mathrm{m}^{2}$ of substrate exposed to colonization by euendoliths 632 when coral substrates were used.

$633 *$ rates measured using microscopy techniques. ** rates measured using the alkalinity 634 technique. $* * *$ rates measured using the buoyant weight technique. Cyano.: Cyanobacteria 635

\begin{tabular}{|c|c|c|c|c|c|}
\hline Source & Location & Type of reef & $\begin{array}{l}\text { Depth } \\
(\mathrm{m})\end{array}$ & $\begin{array}{l}\text { Type of substrate } \\
\text { (\& dominant microborers) }\end{array}$ & $\begin{array}{l}\text { Dissolution rate } \\
\left(\mathrm{mmol} \mathrm{CaCO}_{3} \mathrm{~m}^{-2} \mathrm{~d}^{-1}\right)\end{array}$ \\
\hline Tudhope and Risk (1985) & Australia & Barrier reef & $5-27$ & $\begin{array}{l}\text { Sediments } \\
\text { (undetermined algae/fungi) }\end{array}$ & $10^{*}$ \\
\hline Hoskin et al. (1986) & Bahamas & Intertidal & $2-32$ & $\begin{array}{l}\text { Limestone } \\
\text { (undetermined) }\end{array}$ & $7 * * *$ \\
\hline Chazottes et al. (1995) & French Polynesia & Flat reef & 2 & $\begin{array}{l}\text { Porites lobata } \\
\text { (cyano., Ostreobium, fungi) }\end{array}$ & $3 *$ \\
\hline \multirow[t]{2}{*}{ Vogel et al. (2000) } & Bahamas & Various reefs & $6-30$ & $\begin{array}{l}\text { Limestone } \\
\text { (cyano, algae, fungi) }\end{array}$ & $3-7^{*}$ \\
\hline & & & & $\begin{array}{l}\text { Strombus shells } \\
\text { (cyano, algae, fungi) }\end{array}$ & $<3 *$ \\
\hline Chazottes et al. (2002) & Reunion & Fringing reef & $1-3$ & $\begin{array}{l}\text { P. lobata } \\
\text { (cyano, Ostreobium) }\end{array}$ & $0.5-2 *$ \\
\hline Carreiro-Silva et al. (2005) & Belize & Patch reef & 2 & $\begin{array}{l}\text { Strombus shells } \\
\text { (Plectonema, Phaeophila) }\end{array}$ & $1^{*}$ \\
\hline \multirow[t]{3}{*}{ Tribollet (2008a) } & Australia & Inshore reef & 14 & $\begin{array}{l}\text { P. lobata } \\
\text { (Plectonema, Ostreobium, fungi) }\end{array}$ & $3 *$ \\
\hline & & Barrier reef & 14 & $\begin{array}{l}\text { P. lobata } \\
\text { (Plectonema, Ostreobium, fungi) }\end{array}$ & $8-16^{*}$ \\
\hline & & Offshore pinnacle & 14 & $\begin{array}{l}\text { P. lobata } \\
\text { (Plectonema, Ostreobium, fungi) }\end{array}$ & $30 *$ \\
\hline Tribollet et al. (2009) & Hawaii & Barrier back reef & 3 & $\begin{array}{l}\text { P. lobata } \\
\text { (Plectonema, Ostreobium) }\end{array}$ & $7-9 *$ \\
\hline Reyes-Nivia et al. (2013) & Australia & Barrier reef & Shallow & $\begin{array}{l}\text { P. cylindrica, Isopora cuneate } \\
\text { (Plectonema, Ostreobium) }\end{array}$ & $26-42 * * *$ \\
\hline Present study (TA method) & New Caledonia & Bay (inshore reef) & 14 & $\begin{array}{l}\text { P. lobata } \\
\text { (Plectonema, Ostreobium) }\end{array}$ & $6^{* *}$ \\
\hline Present study (microscopy) & New Caledonia & Bay (inshore reef) & 14 & $\begin{array}{l}\text { P. lobata } \\
\text { (Plectonema, Ostreobium) }\end{array}$ & $7 *$ \\
\hline
\end{tabular}




\section{Figures}

644

645 Figure 1. (A) Photograph of a coral block colonized by 1 year-old euendolithic communities 646 after removal of epiliths. Black arrow indicates a dark green endolithic patch due to

647 Ostreobium sp. White arrow indicates a purplish endolithic patch due to euendolithic 648 cyanobacteria. Scale bar $=1 \mathrm{~cm}$. (B) Ostreobium sp. filaments (black arrows) observed under 649 light microscopy on a thin section coloured by toluidine blue. Scale bar $=30 \mu \mathrm{m}$.

650

651 Figure 2. Metabolic activity of microboring communities dominated by Ostreobium sp. in 652 experimental dead coral skeletons measured under three different saturation state of aragonite $653\left(\Omega_{\text {Arag }}\right.$ ). (a) Net biogenic dissolution of carbonates under daylight (white) and night conditions 654 (grey). (b) Net photosynthesis and respiration under daylight and night conditions, 655 respectively. For clarity, both net photosynthesis and night respiration are shown as positive 656 values. The number in each bar represents the mean value of $\Omega_{\text {Arag }}$ during the incubations. 657 The standard error of each mean is indicated.

658 
(a)
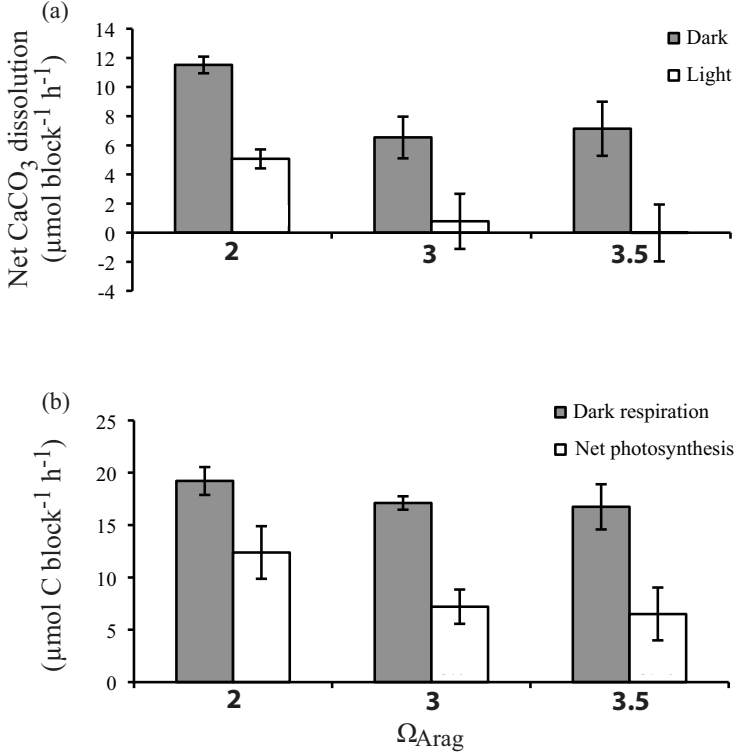